\title{
12 Years a Slave as a Bridge to Primary Source Research
}

\author{
Gordon Mantler, The George Washington University
}

January 1, 2017

\begin{abstract}
This historical analysis essay on the film 12 Years a Slave and several primary sources bridges earlier skills-based writing prompts with the final research project. It asks students to practice several essential writing moves that reflect the disciplinary approach of historians, without forgetting the concerns of film studies and literature scholars, and even filmmakers. Such moves include conducting careful primary source analysis and interrogation as a historian would; beginning to find sources on one's own (rather than being provided already curated materials); and formally analyzing a film in-depth, including commenting on filmmakers' techniques and how such choices impact the content that viewers witness.
\end{abstract}

In the opening scene of 12 Years a Slave, the Oscar-winning film from 2013 about Solomon Northup's kidnapping and enslavement, Northup has a chance sexual encounter with an anonymous, enslaved woman, amid a dozen or more sleeping, also enslaved people. There is nothing sensual about the scene; it ends quickly, and she turns over and weeps softly. The scene is powerful and sad. It also is invented-showing up nowhere in the narrative of the same name written by Northup in 1853. Yet, the scene captures an essential truth of slavery, the trauma, the degradation, the utter lack of privacy and respect of enslaved people (McQueen, 2013). Learning that Northup never mentions such an encounter might be disappointing to some viewers, especially in a film generally praised for its realistic portrayal of slavery and its general faithfulness to the original narrative (Toplin, 2014). But as historian Robert Rosenstone (2012) argues, not only should we expect films to invent, condense, omit, and alter the historical record, such changes actually reflect films' unique "rules of engagement" with the past. History films, Rosenstone suggests, are "not meant to provide literal truths about the past... but metaphoric truths which work, to a large degree, as a kind of commentary on, and challenge to, traditional historical discourse" (2012, pp. 8-9). 
Such a notion remains heretical among many historians, who routinely criticize films for their factual errors, both large and small. And, certainly, some films skew the history so much that historical relevance is all but lost. Despite such concerns, the argument Rosenstone poses has become a driving theoretical force in my introduction to academic writing course, "Writing Race, Filming History," at The George Washington University. The class charges students with critically thinking, reading, and writing about visual culture and how it narrates stories of American history, especially through the category of race. Rather than simply accept that films, especially those produced by Hollywood studios, never can adequately capture the nuance and often competing interpretations of the historical moment, let alone longer historical processes, the course challenges students to consider visual texts on their own terms and not necessarily in contrast to their written counterparts. The result has been a lively, intellectually challenging class that helps students distinguish popular rhetorical features from those of academic discourse and argument, especially within the discipline of history, in which practitioners often privilege original, primary sources over scholarly, secondary texts. Perhaps more than any other prompt, the accompanying assignment on 12 Years a Slave lies at the heart of that pedagogical process.

Simply named "P1 - Analyzing Primary Documents," the assignment is part of a carefully scaffolded series of essays designed to build practical and intellectual skills in academic writing. In the first several weeks of the semester, students write a few informal, lowstakes responses to films we watch as a group, followed by two short but more formal essays using Joseph Harris' concepts of coming to terms, forwarding, and countering to explore several scholars' approaches to history films (2006). In the sixth week of the semester, students write and workshop a first draft of $\mathrm{P} 1$, with a second and final draft submitted approximately two weeks later. Students then embark on their final research project, called P2, which focuses on the discourse of and around a film of the student's choice and takes up the entire second half of the 14-week semester, from library sessions and an annotated bibliography to written and oral drafts.

An assignment I honed for more than a year, P1 emerged as a key bridge between the initial skills-based writing prompts and the final research project. The assignment has a 1,200- to 1,800-word count, twice as long as the earlier essays, and it features two dedicated drafts. Moreover, P1 asks students to practice several essential writing moves that reflect the disciplinary approach of historians, without forgetting the concerns of scholars in film studies and literature, and filmmakers themselves. Such moves include conducting careful primary source analysis as a historian would; beginning to find sources on one's own (rather than being provided already curated materials); and analyzing formally a film in-depth, including commenting on filmmakers' techniques and how such choices impact the content that viewers witness. Essential to the analysis requested is that students carefully interrogate both the film and the corresponding primary sources and not presume that the written documents are automatically more credible than the visual text. 12 Years a Slave, in particular, lends itself to such analysis, and not only because of the film's technical prowess. The film stands up well when considered alongside 
Northup's elegantly written original narrative and other rich materials depicting 19thcentury American slavery, such as additional published slave narratives, the 1930s-era Works Progress Administration's slave interviews, historical newspaper accounts, and posters advertising the internal slave trade.

Much like the film itself, the assignment produces a diverse array of dynamic and engaged writing that often, but not always, praises the film. For some students, 12 Years a Slave best captures how the slavery system degraded everyone it touched. Director Steve McQueen's artful and emotional scenes of brutality-especially whippings-place everyone in a harsh, demeaning light. Students' character studies reflect the complexity of relationships in the plantation world-the hostile and uncaring treatment by plantation mistresses, so often erroneously considered by the public as more sympathetic than masters, or the limited but real negotiation that enslaved men and women conducted to survive, such as the whipping skills that Northup learned or the coerced sex and companionship by enslaved women Eliza, Patsy, and Mistress Shaw. Some of the most interesting moments are when students argue what the film does more effectively than the written texts, including visualizing Northup's disorientation after being kidnapped, the beautiful yet oppressive landscape of the Louisiana bayou, and the constant and distracting background whir of summer insects and forced labor.

While students routinely conclude that primary sources largely corroborate much of McQueen's portrayal of Northup's story, they also take seriously that written documents deserve their own scrutiny. For instance, students question parts of the original narrative, especially those details that seem shaped by the politics of 1850 s abolitionism, targeted to a particular audience, or exposed through subtle but distinct variations in writing style. Some students even suggest that the opening scene-routinely considered invented but ultimately truthful-might actually have occurred, given Northup's possible desire to insulate his wife and family from his own transgressions during enslavement. Students also consistently find an array of compelling sources on their own, including original newspaper coverage of the trials of Northup's kidnappers, slave traders' own accounts, and other interesting materials in historical newspaper and periodical databases. Ultimately, students use the assignment to delve into the texts in thoughtful, creative, and diverse ways in a controlled environment. They are then better prepared to enter an academic conversation and find and interrogate sources in a much longer, more involved analysis of a film of their choosing.

What P1 does not explicitly do is challenge students to consider the film as a historical artifact of 2013. Films are discussed as primary sources in class all semester, starting with Walker, the cult classic and barely veiled critique of historic U.S. intervention in Central America. The final research project and prompt adds this element, as well. But other than a brief wrap-up discussion in class, students do not broach the topic in writing P1. Thus, there are a few questions we do not ask, at least not directly. Does 12 Years a Slave privilege Northup's individual journey over the slave community? And does that narrative reflect, inadvertently or not, the rugged individualist ideology of the 21st century? To consider how films, including 12 Years a Slave, reflect the values and 
concerns of today often poses a deep challenge to students. But it is a challenge I believe might risk the loss of focus on the assignment's most explicit goals, which are to find and adequately interrogate relevant and original sources about the historical moment at hand. Ultimately, the assignment's focus reminds students that primary documents-and not just secondary and scholarly texts-remain central to historical analysis and discourse. It is that unique privilege played by original sources in understanding how change occurs over time that distinguishes historical writing from all others-whether it is the 1850 s or the 21 st century.

\section{Assignment-P1 - Analyzing primary documents}

See the Supplementary Files for this article at thepromptjournal.com for a PDF facsimile of the original formatting of this assignment.

A historian analyzes a primary source by asking a series of questions of the text - not unlike how a scholar might come to terms with another's project, including its structure, tone, materials, and uses and limits. Keep in mind the questions we went over in class. What does the source say on the surface? Is there an argument? Who is the audience? What assumptions does the writer make? What kinds of rhetorical devices does the writer use? Does the source seem credible, and why or why not? In this essay, I want you to first come to terms with several primary sources about the 19th century U.S. slavery experience, keeping the above questions in mind. Read them carefully several times, looking for both their literal and implied meanings, as we did with several documents in class. Then, in 1,200 to 1,800 words (roughly four to six pages), assess how the documents support, challenge, or complicate the slavery experience as depicted in the film 12 Years a Slave. In other words, does the film faithfully reflect the slavery experience, as described in the documents? And, keeping the arguments of Robert Rosenstone and others in mind, is there any element of 19th century slavery that the film does a better job of depicting, in contrast to the written record?

You must use a minimum of four primary sources from a variety of origins, including Solomon Northup's 1854 narrative, 12 Years a Slave, found on Blackboard. While any part of his narrative can be used, especially consider chapters $2,5,10,13,16$, and 21 . In addition, choose at least one document from the following list culled from George Mason University's "History Matters" website:

- "Slaves for sale," 1855 (http://historymatters.gmu.edu/d/6729)

- "My Master Sold Albert to a Trader," 1852 (http://historymatters.gmu.edu/d/6380)

- "We Was Jus' Turned Out Like a Lot of Cattle," 1940 (http://historymatters.gmu.edu/ $\mathrm{d} / 6520)$ 
- "Time Did Not Reconcile Me To My Chains," 1837 (http://historymatters.gmu.edu/ $\mathrm{d} / 6580)$

In addition, you must find at least two relevant primary source on your own, using library resources taught in our sessions with the librarian. Primary materials from the 19th century can be found in several places, especially through the History subject databases on the library website:

- African American Newspapers

- African American Periodicals

- other newspaper databases (i.e. New York Times, New York Herald-Tribune)

- book anthologies of primary materials (by typing in your subject and then "sources" in a catalog search on the Gelman website).

There are many educational institutions with websites devoted to primary sources about slavery, especially slave narratives. Here are three, including two from the Library of Congress:

- Slave Narratives from the Federal Writers Project, 1936-38 (http://lcweb2.loc.gov/ ammem/snhtml/snhome.html)

- Excerpts from Slave Narratives - Steven Mintz, University of Houston (http: //www.vgskole.net/prosjekt/slavrute/primary.htm)

- Slavery and the Courts, 1740-1860 (http://memory.loc.gov/ammem/sthtml/ sthome.html)

Lastly, feel free to use other secondary and scholarly sources as you see fit, including Rosenstone and other film scholars we have already read, other more traditional histories of slavery, and reviews of the film. Here are two of the latter, found under Course Documents:

- Nelson, "Cinematic Slavery"

- Urban, "Art as Ally"

This paper will be written in two drafts. A first full draft of several students' papers will be work-shopped in class in each section; everyone else will receive written thoughts from me. A second and final draft will be turned in for a grade.

This essay's purpose is to combine several skills we have worked on so far. A successful paper:

- analyzes at least four primary documents by interrogating their assumptions and subtexts (reading for both literal and implied meanings), including the Northup narrative

- crafts a clear, concise claim about the documents' value in interpreting slavery 
- supports your claim with specific pieces of evidence - both paraphrased and judiciously quoted - from the documents and other sources cited

- structures the argument effectively, with distinct paragraphs and strong topic sentences

- reads clearly with minimal awkwardness and syntax errors

- uses proper citation (footnote) format, including from the George Mason website

This paper prepares you for P2, in which you analyze even more primary sources to make an argument about a film's ability to narrate a particular historical person, event, or period.

Format: 1,200-1,800 words; 12-point font and 1-inch margins; include name and section at top

Citation form: Chicago or Turabian-style footnotes (see Purdue's Owl website)

First full draft due: week 1, on Blackboard (Assignments - P1 first draft)

(When taught, this assignment was introduced on week 6 of the class. -Eds.)

Final draft due: two weeks later, on Blackboard (Assignments - P1 final)

\section{References}

Harris, J. (2006). Rewriting: How to do things with texts. Logan, Utah: Utah State University Press.

McQueen, S. (2013). 12 years a slave. Fox Searchlight Pictures.

Rosenstone, R. (2012). History on film/Film on history (2nd ed.). New York, NY: Routledge.

Toplin, R. (2014). 12 years a slave examines the old South's heart of darkness. Perspectives on History, 52(1), 39-40. 